Jorge Andrés Muñoz-Mendoza"

Sandra María Sepúlveda-Yelpo"

Carmen Lissette Veloso-Ramos" Carlos Leandro Delgado-Fuentealba

Recibido: 30 de marzo de 2020

Concepto de evaluación: 5 de agosto de 2020

Aprobado: 13 de agosto de 2020

Artículo de investigación

(C) 2020 Universidad Católica de Colombia.

Facultad de Ciencias

Económicas y Administrativas.

Todos los derechos reservados

"M.Sc. in Finance and M.Sc. in

Economics. Assistant Professor, Department of Business Management,

Universidad de Concepción, Chile.

(D) https://orcid.org/0000-0002-6775-5307.

Email: jormunozm@udec.cl

${ }^{* *}$ M.Sc. in Finance and MBA in Administration. Assistant Professor, Department of Business Management,

Universidad de Concepción, Chile.

(iD https://orcid.org/0000-0002-2614-7356.

Email: ssepulveday@udec.cl

*** BA in Management and MBA in

Administration. Professor, Department of Business Management, Universidad de Concepción, Chile.

(iD https://orcid.org/0000-0001-9390-9974.

Email: carmenveloso@udec.cl

**** Commercial Engineer and M.Sc. in Economics. Instructor, School of Management and Business Studies, Universidad de Concepción, Chile. (D) https://orcid.org/0000-0001-7656-3254. Email: cadelgado@udec.cl
Revista Finanzas y Política Económica, Vol. 12, N.ํ2, julio-diciembre, 2020, pp. 341-365 https://doi.org/10.14718/revfinanzpolitecon.v12.n2.2020.3270

\section{Market Concentration and Income Diversification: Do They Always Promote the Financial Stability of Banking Industry? ${ }^{1}$}

\begin{abstract}
This paper analyzes the effects of market concentration and income diversification on the financial stability of the world banking system. It uses the GMM estimator proposed by Arellano and Bover (1995) to study 206 countries between 1994 and 2015. The results show that market concentration and income diversification have a positive and nonlinear effect on financial stability; and a negative and nonlinear effect on bank risk. The nonlinearity shape suggests that the effects are reversed when the banking industry has a higher market concentration and income diversification. In these cases, lower levels of stability and higher risks would characterize the banking industry. Nonlinearity establishes threshold values that are relevant for the empirical discussion oriented to an optimal design of financial policies and banking strategies.
\end{abstract}

Keywords: financial stability, bank risk, market concentration, income diversification.

JEL Classification: E44, E58, G18, G21.

The Office of Research at the Universidad de Concepción funded this research (218.420.004-1.0 VRID Project). We appreciate the valuable comments of those attending the 2019 Global Conference on Business and Finance (Costa Rica). The errors that persist are the authors' responsibility. 


\section{Concentración de mercado y diversificación de ingresos: ¿siempre promueven la estabilidad financiera de la industria bancaria?}

\section{Resumen}

En este artículo se analizan los efectos de la concentración de mercado y diversificación de ingresos sobre la estabilidad financiera de la banca en el ámbito mundial. Usamos el estimador GMM de Arellano y Bover (1995) para una muestra de 206 países entre 1994 y 2015. Los resultados demuestran que la concentración de mercado y la diversificación de ingresos tienen un efecto positivo y no lineal sobre la estabilidad financiera; y negativo y no lineal sobre el riesgo. La no linealidad sugiere que sus efectos se reversan cuando la industria bancaria tiene una elevada concentración y diversificación, observándose una industria menos estable y más riesgosa. La no linealidad establece valores umbrales que son relevantes para el diseño óptimo de políticas financieras y estrategias bancarias.

Palabras clave: estabilidad financiera, riesgo bancario, concentración de mercado, diversificación de ingresos. 


\section{INTRODUCTION}

During the last two decades, the worldwide banking industry has experienced significant changes in its market structure and nature of its financial services. Countries with more concentrated banking industries and more diversified product portfolio became more usual. Such changes increased the interest of researchers in studying their implications on the financial stability of banks as well as its risks. Although there are several studies that have analyzed the effects of market structure and income diversification on bank risk taking, there is no clear consensus.

Regarding the effects of market concentration on the financial stability of the banking sector, many studies have initially shown that banking industry concentration promotes financial stability because this type of structure would favor the reduction of information asymmetry and risk exposure for banks (Keeley, 1990; Allen \& Gale, 2000; Hellmann et al., 2000). However, more recent studies have reopened the debate, arguing that market concentration reduces financial stability. These studies argue that a more concentrated banking market usually charges higher interest rates, which leads borrowers to take higher risks (Boyd \& De Nicolo, 2005; Berger et al., 2009; Martinez-Miera \& Repullo, 2010).

There is a similar debate about the effects of income diversification on financial stability. Some studies indicate that income diversification increases the financial stability of banks as it would strengthen bank efficiency in terms of costs and risk redistribution (Boyd \& Graham, 1988; Rose, 1989; Landi \& Venturelli, 2001). Other studies indicate a different view, arguing that diversification would increase bank income volatility since it would be supported by non-traditional activities in which banks lack experience (DeYoung \& Roland, 2001; Mercieca et al., 2007; Berger et al., 2010a; Batten \& Vo, 2016).

The subprime crisis has also left important lessons and reopened the debate about how these factors acted on the financial crisis of the United States during 2008. Contrary to several studies, the development of riskier and diversified activities by American banks showed the fragility of a concentrated and diversified banking industry. This lack of consensus about the effects of market concentration and income diversification on financial stability leads us to believe that such impacts would be non-persistent and even nonlinear. A relationship of this nature would suppose the existence of threshold values for the effects of market concentration and diversification on banking industry stability, which would be useful for financial policy design. It would also be relevant for banks because it would allow them 
Jorge Andrés Muñoz-Mendoza • Sandra María Sepúlveda-Yelpo • Carmen Lissette Veloso-Ramos • Carlos Leandro Delgado-Fuentealba

to design their diversification strategies and incentives for action within the industry. Furthermore, policy makers of each country are interested in strengthening financial stability. Many of them are requiring certain standards to converge to the Basel III regulatory framework. In this scenario, this paper provides a source of information about guidelines and threshold values for the degree of market concentration and income diversification. These values are useful to strengthen the stability and risk management of banks.

Therefore, the purpose of this research is to analyze the effects of market concentration and income diversification on financial stability in the banking industry. Our contributions to international evidence can be summarized in two points. First, we evaluate the potential nonlinear effect of market concentration on financial stability and risk in the banking industry. Our interest is to evaluate the possible tradeoff between the monopolistic behaviors of banks and borrowers' incentives to take risks. Second, we also analyze a possible nonlinear effect of income diversification on financial stability. We believe that economies of scope and economies of scale also lead to a trade-off on financial stability in the banking industry.

We use a sample of 206 countries extracted from World Bank databases for the period 1994-2015. Our results indicate that market concentration and income diversification have positive effects on financial stability, and negative effects on bank risk. However, their effects are not persistent because their relationship is not linear, being reversed for high levels of market concentration and income diversification. In this way, when the industry has these characteristics, the financial stability of the banking market is reduced and its risk increases. These results are relevant for banks because they allow them to evaluate the effects of income diversification strategies, to know concentration limits within the banking market, and their effects on bank solvency and on the economic system. They are also relevant for policymakers because these results provide them evidence for the design of a financial policy aimed at regulating the structure and activities of the banking market.

This article is structured as follows. After this introduction, Section 2 presents a literature review about the relationship between market concentration and income diversification on financial stability in the banking industry. This section also points out the research hypotheses. Section 3 presents the data and analysis methodologies, while Section 4 shows the results obtained. Finally, Section 5 indicates the conclusions and main implications of this research. 


\section{THEORETICAL FRAMEWORK AND HYPOTHESIS DEVELOPMENT}

\section{Effects of Market Concentration on Financial Stability}

Several researches have highlighted the role of the banking market structure in financial stability. Initial studies on this subject show that market concentration generates higher financial stability. This is an idea that has been accepted by many researchers, policymakers, and economists. However, during the last fifteen years, new works have contributed contrary evidence, generating a greater debate around this relationship.

Diverse studies have argued that there is a positive relationship between banking market concentration and financial stability level, relationship that has been analyzed through various channels such as the performance, risk, and efficiency of banks. The seminal works of Klein (1971) and Monti (1972) indicate that banking concentration allows banks to have higher market power and profitability. From the same point of view, Keeley (1990) adds that market power would facilitate a greater degree of stability within the banking industry. Empirically, Boyd et al. (2006) analyzed 134 countries between 1993 and 2004, and they corroborated that bank concentration increases the performance and stability of the industry. Same results are provided by Uhde and Heimeshoff (2009) in a study for 25 Eurozone countries between 1997 and 2005. This vision, known as the competition-fragility theory, has been supported by many other empirical works (Allen \& Gale, 2000; Hellmann et al., 2000; Carletti \& Vives, 2009; Jeon \& Kyu, 2013). The positive relationship between market concentration and financial stability would also be associated with an information asymmetry reduction and lower risk exposure by borrowers and bank owners (Besanko \& Thakor, 1993). Normally, market concentration involves few and large banks in the industry. These conditions facilitate information gathering by these institutions and mitigate the moral hazard and adverse selection problems regarding borrowers (Chan et al., 1986; Marquez, 2002; Hauswald \& Marquez, 2006; Freixas \& Rochet, 2008; Fernández et al., 2010). Similarly, Matutes and Vives (2000) add that banking market concentration also limits the risk exposure of the shareholders and managers of banks and encourages them to better select their customers. These decisions are aligned with banking system strengthening and lower bank run probability (Smith, 1984). In the same line, other studies add that a concentrated banking system is less risky because it has higher capital levels that allow it to absorb losses 
Jorge Andrés Muñoz-Mendoza • Sandra María Sepúlveda-Yelpo • Carmen Lissette Veloso-Ramos • Carlos Leandro Delgado-Fuentealba

and counteract the crisis effects (Beck et al., 2006; Berger et al., 2009; Vives, 2016). Many other studies confirm this positive relationship between market concentration and financial stability (Petersen \& Rajan, 1995; Turk-Ariss, 2010; Jiménez et al., 2013; Mirzaei et al., 2011; Agoraki et al., 2011; Beck et al., 2013).

However, during the last fifteen years, several studies appeared that provided results contrary to those described, establishing a trade-off between banking market concentration and financial stability. The work of Boyd and De Nicolo (2005) demonstrated a negative relationship between market concentration and financial stability, which is based on the borrowers' risk preferences. These authors argue that in a concentrated banking industry, banks charge higher interest rates. These higher interest rates encourage borrowers to take greater risks in their consumption and investment decisions, which would ultimately increase bank risk. This behavior accentuates the adverse selection problem on the banks' customer portfolio (Stiglitz \& Weiss, 1981). Goddard et al. (2004) analyze European banks and indicate that risk increase is more pronounced in small banks that have low market share. These banks operate in specific and riskier niches. The authors argue that as long as there are large banks that excessively concentrate the industry, it encourages the creation of small financial institutions, which accentuates the risk and adverse selection problems throughout the industry. This view has also been confirmed by other researches (Demirgüç-Kunt \& Huizinga, 2000; Schaeck et al., 2009; Berger et al., 2009; Liu et al., 2012; Soedarmono et al., 2013; Jeon \& Kyu, 2013). These results suggest that the negative effect of market concentration on financial stability would be observed when banking concentration is high.

The analyzed empirical results and the lack of consensus observed in them lead us to believe that the relationship between market concentration and financial stability is nonlinear, and that it would depend on the concentration degree of the banking industry. As pointed out by Boyd and De Nicolo (2005) and Martinez-Miera and Repullo (2010), high interest rates would reflect a highly concentrated banking industry, with greater exposure to borrower risk. However, when market concentration is low, higher profitability and lower costs of information obtained by banks would lead to a greater degree of stability (Tabak et al., 2012). With these arguments we propose our first hypothesis:

H1: Banking market concentration has a nonlinear effect on financial stability. 


\section{Effects of Income Diversification on Financial Stability}

Income diversification is based on economies of scope that banks develop through non-traditional activities, such as securities trading, insurance, and investments, among others. Banking products have a common production technology that allows banks to reduce costs through the joint development of various financial services. This fact leads the banking industry to a multi-product nature (Gregoire \& Mendoza, 1990). However, the effects of income diversification on financial stability are another focus of debate that has attracted the researchers' interest.

Regarding the relationship between income diversification and financial stability, empirical opinions are divided. Several studies argue that income diversification increases banking stability. Boyd and Graham (1988) and Boyd et al. (1993) showed that US banks reduced their risk level from merger with their insurance companies. Rose (1989) adds that when banks develop non-traditional activities, the volatility of their cash flows and risk are reduced. Landi and Venturelli (2001) argue that income diversification strengthens the efficiency of banks in terms of costs and profits. The authors add that this strengthening allows banks to redistribute risk and stabilize their performance. It is even possible that the systematic risk of banks is also reduced (Templeton \& Severiens, 1992). More recently, in an analysis of 967 banks from 22 countries of Asia, Lee et al. (2014) show that non-traditional activities reduce the risk of banks and strengthen their financial stability. Under these arguments, many other empirical studies have demonstrated the positive relationship between income diversification and banking financial stability (Shim, 2013; Köhler, 2015; Tsai et al., 2015). Even the positive effects of income diversification on financial stability would be consistent with a concentrated market structure, where the efficiency of large banks would be achieved through distributing the production cost over a diversified portfolio of financial services (Williamson, 1986; Beck et al., 2007).

Other studies indicate an opposite point of view about the effects of income diversification on financial stability. These researches argue that income diversification has collateral effects such as increased risk and banking performance instability (Stiroh, 2004a, 2004b, 2006; Stiroh \& Rumble, 2006; Demirgüç-Kunt \& Huizinga, 2010). In a study conducted for Chinese banks, Berger et al. (2010b) show that income diversification increases risk and bank costs. Amidu and Wolfe (2013), in a study of 978 banks from 55 emerging countries, show that income diversification reduces the financial stability of banks. DeYoung and Roland (2001) warn that the replacement of traditional activities by non-traditional ones would increase bank income volatility 
Jorge Andrés Muñoz-Mendoza • Sandra María Sepúlveda-Yelpo • Carmen Lissette Veloso-Ramos • Carlos Leandro Delgado-Fuentealba

as well as its risk. The authors add that this fact stimulates banks to specialize on banking activities. Mercieca et al. (2007) add that when banks develop businessdiversified lines in which they lack experience, financial stability gets reduced. In this matter, Chiorazzo et al. (2008) argue that income diversification establishes a trade-off between risk and return, which conditions its impact on financial stability. In fact, the impossibility of obtaining higher advantages from economies of scope that promote income diversification would be due to an adverse selection problem on banking services portfolio. These findings indicate that a higher income diversification accentuates the adverse selection problem, increasing banking risk and reducing its financial stability level, while for low levels of income diversification, greater advantages would be observed from economies of scope. Based on these arguments, we believe that the impact of income diversification on financial stability is nonlinear. In this way, we formulate this hypothesis:

H2: Income diversification has a nonlinear effect on financial stability.

\section{DATA AND METHODS}

\section{Data}

Research data were extracted from World Bank databases, specifically from the Global Financial Development Database (GFD) and the World Development Indicators (WDI). The information was organized in a panel data for 206 countries between 1994 and 2015. Of these countries, 194 are officially recognized by the United Nations Organization, while 12 have limited or no recognition. Table 1 shows the geographical distribution and income level of the countries. $33.01 \%$ of the countries are high-income, half of which are located in Europe, Central Asia, the Asia-Pacific region, and Latin America; while $15.05 \%$ of them are low-income countries, located mainly in sub-Saharan Africa.

Table 2 presents the description of variables. The dependent variable is financial stability (FINST), measured by bank Z-score and banking risk index. The latter is quantified through the non-performing loans to total loans ratio. It is important to highlight that both measures evaluate the stability-risk relationship inversely, being the main measures used by several empirical studies (Boyd et al., 2006; Berger et al., 2009; Laeven \& Levine, 2009; Turk-Ariss, 2010; Jeon \& Kyu, 2013). 


\section{Sample Composition, Percentage (Countries)}

\begin{tabular}{|c|c|c|c|c|c|c|}
\hline \multirow{2}{*}{ Geographic Zone } & \multicolumn{5}{|c|}{ Country Classification by Income Level } \\
\cline { 2 - 6 } & High & Upper-Middle & Lower-Middle & Low & Full Sample \\
\hline \multirow{2}{*}{ East Asia and the Pacific } & $5.34 \%$ & $3.40 \%$ & $7.28 \%$ & $0.49 \%$ & $16.50 \%$ \\
\hline \multirow{2}{*}{ Europe and Central Asia } & 11 & 7 & 15 & 1 & 34 \\
\hline \multirow{2}{*}{ Latin America and the Caribbean } & $16.50 \%$ & $6.80 \%$ & $3.40 \%$ & $0.00 \%$ & $26.70 \%$ \\
\cline { 2 - 6 } & 34 & 14 & 7 & 0 & 55 \\
\hline \multirow{2}{*}{ Middle East and North Africa } & $5.34 \%$ & $9.71 \%$ & $2.43 \%$ & $0.49 \%$ & $17.96 \%$ \\
\hline \multirow{2}{*}{ North America } & $3.88 \%$ & $2.91 \%$ & $3.40 \%$ & $0.00 \%$ & $10.19 \%$ \\
\hline \multirow{2}{*}{ South Asia } & 8 & 6 & 7 & 0 & 21 \\
\hline \multirow{2}{*}{ Sub-Saharan Africa } & $1.46 \%$ & $0.00 \%$ & $0.00 \%$ & $0.00 \%$ & $1.46 \%$ \\
\hline \multirow{2}{*}{ Full Sample } & 3 & 0 & 0 & 0 & 3 \\
\hline & $0.00 \%$ & $0.49 \%$ & $2.43 \%$ & $0.97 \%$ & $3.89 \%$ \\
\hline & 0 & 1 & 5 & 2 & 8 \\
\hline & $0.49 \%$ & $3.40 \%$ & $6.31 \%$ & $13.11 \%$ & $23.30 \%$ \\
\hline & 1 & 7 & 13 & 27 & 48 \\
\hline & $33.01 \%$ & $26.70 \%$ & $25.24 \%$ & $15.05 \%$ & $100 \%$ \\
\hline
\end{tabular}

Source: Authors elaboration.

According to other international studies, the banking market concentration is measured through two complementary ways. On the one hand, we use the Lerner index, which is usually used as an indicator of market power (Liu et al., 2012; Soedarmono et al., 2013; Jeon \& Kyu, 2013). The Lerner index oscillates between 0 and 1; extremes that mark a competitive and monopolistic market structure, respectively. Any value within this range indicates a non-competitive market structure for a country's banking industry (Klein, 1971; Monti, 1972). On the other hand, we use the five largest banks' asset concentration to quantify market concentration (Molyneux \& Thornton, 1992; Athanasoglou et al. 2008). These measures have been widely used by other empirical studies (Keeley, 1990; Allen \& Gale, 2000; Hellmann et al., 2000; Berger et al., 2009). It is important to note that the Lerner index is a measure of competition and not market concentration. However, Chen and Liao (2011) warn that a higher Lerner index reveals less competitive behavior by banks and a trend towards market concentration. In this sense, our calculations support this argument and show that the correlation between the Lerner index and the asset concentration ratio was 0.10 and statistically significant. 
Jorge Andrés Muñoz-Mendoza • Sandra María Sepúlveda-Yelpo • Carmen Lissette Veloso-Ramos •

Carlos Leandro Delgado-Fuentealba

Table 2

\section{Variables}

\begin{tabular}{|c|c|}
\hline Variable & Description \\
\hline \multicolumn{2}{|c|}{ Dependent Variable: Financial Stability } \\
\hline Bank Z-score & Financial stability measured by bank Z-score index \\
\hline Bank risk & Non-performing loans to gross bank loans ratio \\
\hline \multicolumn{2}{|c|}{ Market Structure and Bank Diversification } \\
\hline Lerner index & $\begin{array}{l}\text { Market structure index. It varies between } 0 \text { (competitive market) } \\
\text { and } 1 \text { (concentrated market) }\end{array}$ \\
\hline Five largest banks' assets & $\begin{array}{l}\text { Assets accumulated by the five largest banks in a country on total } \\
\text { banking assets }\end{array}$ \\
\hline Bank diversification & Bank noninterest income to total income ratio \\
\hline \multicolumn{2}{|l|}{ Banking Industry-Level Variables } \\
\hline Bank capital & Bank capital and reserves to total assets ratio \\
\hline Bank liquidity & Bank deposits to GDP \\
\hline Bank performance & Return on assets. Net income to total assets ratio \\
\hline Bank development & Domestic credit provided by banking sector to GDP \\
\hline Operating efficiency & Gross margin ratio of the banking industry \\
\hline \multicolumn{2}{|l|}{ Macroeconomic-Level Variables } \\
\hline Economic growth & Annual GDP growth \\
\hline Inflation & Annual inflation rate \\
\hline Political stability & $\begin{array}{l}\text { Political stability index that ranges between }-2.58 \text { (low stability) and } \\
2.58 \text { (high stability) }\end{array}$ \\
\hline Economic crisis & $\begin{array}{l}\text { Dummy } 1 \text { in the years that countries face economic or financial } \\
\text { crises, and } 0 \text { otherwise (includes Asian, subprime and local crises) }\end{array}$ \\
\hline
\end{tabular}

Source: Authors elaboration.

We also incorporate other control variables suggested by diverse empirical studies. At the banking-industry level, we use the capitalization ratio as a way to incorporate the impact of bank financing on stability and risk (Goddard et al., 2008; Mirzaei et al., 2011); the deposits to credit ratio as liquidity and growth opportunity measure for banks (Maudos \& Solís, 2009; Yahya et al., 2017); return on assets as a banking global performance measure (Jara et al., 2014); as well as the bank credits to GDP ratio as a proxy for the country's banking development (King \& Levine, 1993). We also use the gross margin ratio to quantify the role of operational efficiency (Martinez-Peria and Mody, 2004; Gelos, 2009).

At the macroeconomic level, economic growth, annual inflation, and a dummy variable that takes value 1 in the periods in which countries face economic or financial crises, and 0 otherwise, are incorporated as control variables. These variables follow 
the suggestions of Demirgüç-Kunt et al. (2004), Mirzaei et al. (2011), and Yahya et al. (2017), among others.

\section{Econometric Methodology}

To estimate the possible nonlinear effect of market concentration and income diversification on the financial stability of banks, we use the GMM estimator proposed by Arellano and Bover (1995). The empirical panel data model is the following:

$$
\begin{aligned}
\text { FINST }_{i t}=\beta_{0}+ & \beta_{1} \text { IINST }_{i t-1}+\beta_{2} M C_{i t}+\beta_{3} M C^{2}{ }_{i t}+\beta_{4} D I V_{i t}+\beta_{5} D I V_{i t}^{2} \\
& +\sum_{b}^{B} \beta_{b} X_{b i t}+\sum_{m}^{M} \beta_{m} X_{m i t}+\eta_{i}+\eta_{t}+\varepsilon_{i t}
\end{aligned}
$$

Where FINST $_{i t}$ is the dependent variable that measures the financial stability of the banking industry of country $i$ in period $t$. According to Table 2, financial stability is measured through the Z-score index of the banking industry and the risk associated with non-performing loans. With this, we will analyze the effects of market concentration and income diversification on stability and risk in the banking industry, addressing the endogeneity problem between both variables. The variable $M C_{i t}$ measures the banking market concentration through the Lerner index and the five largest banks' asset concentration. Income diversification $\left(D I V_{i t}\right)$ is measured through the non-traditional income to total income ratio. Note that Model [1] incorporates the variables $M C^{2}{ }_{i t}$ and $D I V^{2}{ }_{i t}$ to control the possible nonlinear effects of market concentration and income diversification on financial stability. In addition, $B_{2} /\left(1-\beta_{1}\right)$ is the long-run marginal effect of market concentration on banking performance, and $\beta_{4} /\left(1-\beta_{1}\right)$ is the long-run marginal effect of diversification on banking performance, while $\beta_{2}$ and $\beta_{4}$ are the short-run marginal effects of market concentration and diversification on banking performance, respectively. Model [1] incorporates a set of control variables, both at the banking industry $(b)$ level and at the macroeconomic $(m)$ level, grouped in the $X_{b i t}$ and $X_{m i t}$ matrices, respectively. Finally, $\varepsilon_{i t}$ is a random disturbance.

Model [1] includes individual fixed-effects $\eta_{i}$ linked to country $i$ and temporary effects $\eta_{t}$ related to year $t$. The dynamic model proposed by Arellano and Bover (1995) was used to control the endogeneity problem originated by the lag in $t-1$ of the dependent variable of each model and the bank risk (Stiglitz \& Weiss, 1981). These variables were instrumentalized through lags $t-2$ and $t-3$ because these instruments 
Jorge Andrés Muñoz-Mendoza • Sandra María Sepúlveda-Yelpo • Carmen Lissette Veloso-Ramos • Carlos Leandro Delgado-Fuentealba

are correlated with endogenous variables, but not with the error. In this case, $F I N S T_{t-1}$ and bank risk were treated as endogenous variables, while the other control variables were considered as exogenous variables. Judson and Owen (1999) suggest that the lags used as instruments may be few or all. In the latter case, the loss of efficiency is not significant in relation to using few lags. For the model to be correctly specified, Arellano and Bover (1995) point out that these estimators must be consistent, and the model must be instrumentally overidentified. To ensure the GMM estimators' consistency, the presence of first-order autocorrelation is necessary, but not of a higher order; while the model's instrumental overidentification is verified through the Sargan test. We use robust variance to control the heteroskedasticity patterns. Model [1] also includes dummies associated with region and income level as control variables.

\section{EMPIRICAL RESULTS}

\section{Descriptive Analysis}

Table 3 shows descriptive and correlational statistics. The financial stability of the banking industry, measured by the Z-score index, has an average value of 12.52; while its risk level, quantified by percentage of non-performing loans, is $7.22 \%$. Within this figure, the opposite behavior between high- and low-income countries stands out. High-income countries have banking industries characterized by high levels of stability and low levels of risk, while the figures of the banking systems of low-income economies are below the world average. The correlation between banking stability and risk is negative and significant, which indicates a possible trade-off between these variables and which the literature has highlighted as an endogenous relationship.

The variables of banking market concentration indicate a non-competitive structure. The Lerner index has an average value of 0.23 , while the five largest banks concentrate $80.62 \%$ of the country's banking assets. The results also reveal a heterogeneous pattern of market structures according to the countries' income levels, where the countries with lower incomes have more concentrated banking industries. In any case, it is observed that both market concentration measures correlate positively and significantly with the Z-score index, although not significantly with the risk. This fact preliminarily reveals that banking market concentration would promote financial stability. 
Market Concentration and Income Diversification: Do They Always Promote the Financial Stability of Banking Industry?

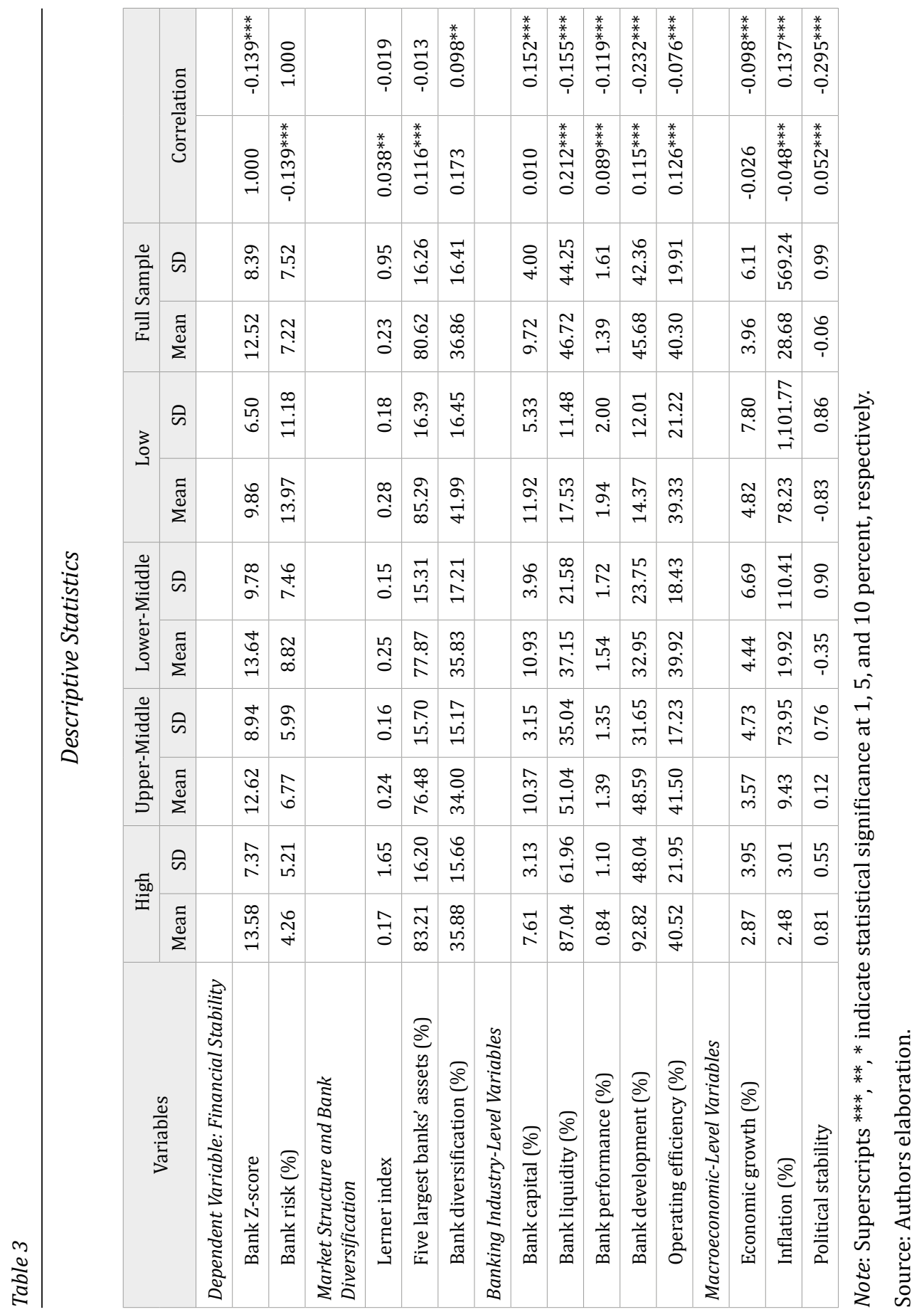


Jorge Andrés Muñoz-Mendoza • Sandra María Sepúlveda-Yelpo • Carmen Lissette Veloso-Ramos • Carlos Leandro Delgado-Fuentealba

Income diversification indicates that $36.86 \%$ of bank income comes from nontraditional activities, where high-income countries have records of diversification above the world average. We observe a positive correlation between income diversification and bank risk that shows that these strategies would increase industry risk.

The banking industry variables show interesting results for the analysis. On average, 9.72\% of bank assets are financed with capital, which accounts for a high dependence of banks on external financing. This description is consistent with higher levels of capital required in low-income countries and positive correlation with bank risk. The performance and efficiency of banks indicate a return on assets of $1.39 \%$ and a gross margin of $40.30 \%$, where low-income countries have high records in these measures. Normally, and according to the observed correlations, countries with more stable (or less risky) banking industries are characterized by higher levels of performance and efficiency to control operational costs. The average bank liquidity is $46.72 \%$ and the degree of banking development is $45.68 \%$. High-income countries show the highest records.

Regarding the macroeconomic characteristics, an annual growth of $3.96 \%$ is observed. At this point, there stands out a decoupling between the low growth of high-income countries and the higher economic activity of low-income countries, whose growth is above the global average. Additionally, low-income countries also have the highest inflation records. Institutional development, measured by the political instability index, indicates that high-income countries have higher political stability than other countries, and institutional development is positively correlated with financial stability.

\section{Effects of Market Concentration and Income Diversification on Financial Stability}

Table 4 shows the results of Model [1]. It should be noted that both models meet the specification conditions indicated by Arellano and Bover (1995). The GMM estimators are consistent because the z-test reveals the presence of first-order autocorrelation, while it discards the second-order autocorrelation. In addition, the Sargan test reveals that both models are instrumentally overidentified, while the VIF test indicates that multicollinearity is not significant on the model specification.

Regarding some control variables, the results are the expected. Table 4 shows

that financial stability and banking risk are negatively and significantly related. 
This supports the existence of a trade-off between these banking industry characteristics (Besanko \& Thakor, 1993; Allen \& Gale, 2000; Hellmann et al., 2000; Carletti \& Vives, 2009; Jeon \& Kyu, 2013). In addition, Table 4 indicates that higher capital requirements, liquidity, performance, banking development, and operational efficiency significantly increase the financial stability of banks (and reduce their risk), which is in line with several previous studies (King \& Levine, 1993; Martinez-Peria \& Mody, 2004; Goddard et al., 2008; Maudos \& Solís, 2009; Mirzaei et al., 2011; Yahya et al., 2017).

The findings show that market concentration, measured through the Lerner index and the five largest banks' asset concentration, has a positive and significant effect on financial stability and a negative effect on bank risk. A $1 \%$ increase in the Lerner index generates a 2.75 -point increase in the Z-score and a $0.57 \%$ fall in operational risk, while a $1 \%$ increase in the bank asset concentration ratio increases by 9 points the Z-score index and reduces operational risk by $0.12 \%$. In this way, market concentration would boost the financial strength of banks, inhibit the risk exposure of bank insiders, and redistribute the risk of the banks' customer portfolio. These results support the competition-fragility theory that has been accepted by many empirical studies (Keeley, 1990; Besanko \& Thakor, 1993; Petersen \& Rajan, 1995; Allen \& Gale, 2000; Boyd et al., 2006; Uhde \& Heimeshoff, 2009; Fernández et al., 2010; Beck et al., 2013). Indeed, these effects are significant in the long term. However, the effect of market concentration is nonlinear, which validates hypothesis H1. In this way, this effect on financial stability and banking risk is non-persistent and reversed for high levels of market concentration. In fact, when the Lerner index and the five largest banks' asset concentration exceed the average critical values of 0.40 and $83.76 \%$, respectively, financial stability is reduced and bank risk increases. Our estimates reveal that 707 observations are located above the threshold value of the Lerner index and whose average is 0.57 , while 2079 observations are located below that value, registering an average of 0.28 . Regarding the bank asset concentration ratio, we see that 895 observations are located above the level of $83.76 \%$, averaging $94.04 \%$, while 1891 observations are below that value and record an average of $79.62 \%$. The second effect would be consistent with the approaches of Stiglitz and Weiss (1981) and Boyd and De Nicolo (2005), where adverse selection costs over the banks' customer portfolio raise their risk and reduce their performance, and with it their stability. Other studies provide similar arguments (Schaeck et al., 2009; Liu et al., 2012; Soedarmono et al., 2013).

Income diversification strategies also significantly affect the stability of the banking industry. We observe that income diversification positively affects, both in 
Jorge Andrés Muñoz-Mendoza • Sandra María Sepúlveda-Yelpo • Carmen Lissette Veloso-Ramos • Carlos Leandro Delgado-Fuentealba

the short and long terms, the Z-score index, and negatively the risk associated with non-performing loans. A 1\% increase in the non-traditional income ratio generates an increase of 12.59 in the Z-score index and a $0.16 \%$ fall in the non-performing loans ratio (average of the coefficients). These results indicate that the economies of scope, which sustain a multi-product banking industry, promote financial stability and mitigate the sector's risk. As several studies indicate, this effect leads to strengthened banking efficiency for cost and profit control, as well as to the reduction of income volatility in these institutions (Rose, 1989; Templeton \& Severiens, 1992; Beck et al., 2007; Shim, 2013; Tsai et al., 2015). In any case, the described effect is not persistent because the relationship between financial stability and income diversification is not linear. This result supports the hypothesis $\mathrm{H} 2$ and indicates that the diversification level establishes a trade-off between economies of scope that induce diversification and economies of scale that promote specialization (Chiorazzo et al., 2008). In fact, when the percentage of non-traditional income in relation to total income exceeds the critical average level of $36.82 \%$, the benefit of the economies of scope vanishes, transforming income diversification into a feature that reduces banking stability and increases risk. Our estimates indicate that 1383 observations are located above the threshold value of the diversification ratio and whose average is $50.72 \%$, while 1403 observations are located below that value, registering an average of $24.91 \%$. This second effect is observable for high levels of income diversification and is in line with other studies (Stiroh, 2004a, 2006; Stiroh \& Rumble, 2006; Amidu \& Wolfe, 2013).

Table 4

Dynamic Panel Data Regression for Banking Stability

\begin{tabular}{|c|c|c|c|c|}
\hline \multirow{2}{*}{ Variables } & \multicolumn{4}{|c|}{ Dependent variable is financial stability } \\
\hline & \multicolumn{2}{|c|}{ Bank Z-Score } & \multicolumn{2}{|c|}{ Bank Risk } \\
\hline \multirow{2}{*}{ Constant } & 2.0136 & -1.382 & 0.0218 & 0.0191 \\
\hline & $(1.13)$ & $(-0.45)$ & $(0.91)$ & $(0.38)$ \\
\hline \multirow{2}{*}{ Bank Z-score $_{\mathrm{t}-1}$} & $0.4482^{* * *}$ & $0.4503^{* * *}$ & & \\
\hline & $(19.46)$ & $(20.28)$ & & \\
\hline \multirow{2}{*}{ Bank risk } & $-5.1832^{* *}$ & $-5.7493^{* * *}$ & & \\
\hline & $(-2.49)$ & $(-3.28)$ & & \\
\hline \multirow{2}{*}{ Bank risk $_{\mathrm{t}-1}$} & & & $0.5928^{* * *}$ & $0.6027^{* * *}$ \\
\hline & & & $(27.03)$ & $(22.89)$ \\
\hline \multirow{2}{*}{ Bank Z-score } & & & $-0.0028^{* * *}$ & $-0.0034^{* * *}$ \\
\hline & & & $(-3.42)$ & $(-3.19)$ \\
\hline
\end{tabular}


Market Concentration and Income Diversification: Do They Always Promote the Financial Stability of Banking Industry?

\begin{tabular}{|c|c|c|c|c|}
\hline \multirow{2}{*}{ Variables } & \multicolumn{4}{|c|}{ Dependent variable is financial stability } \\
\hline & \multicolumn{2}{|c|}{ Bank Z-Score } & \multicolumn{2}{|c|}{ Bank Risk } \\
\hline \multicolumn{5}{|c|}{ Bank Diversification and Market Structure } \\
\hline \multirow{2}{*}{ Lerner index } & $2.7536^{* * *}$ & & $-0.5728^{* * *}$ & \\
\hline & $(2.87)$ & & $(-2.94)$ & \\
\hline \multirow{2}{*}{ Lerner index ${ }^{2}$} & $-3.8842^{* * *}$ & & $0.6437^{* * *}$ & \\
\hline & $(-3.02)$ & & $(3.14)$ & \\
\hline \multirow{2}{*}{ Five largest banks' assets } & & $9.8951^{* * *}$ & & $-0.1216^{* *}$ \\
\hline & & $(2.93)$ & & $(-2.47)$ \\
\hline \multirow{2}{*}{ Five largest banks' assets ${ }^{2}$} & & $-6.0175^{* * *}$ & & $0.0712^{* * *}$ \\
\hline & & $(-2.66)$ & & $(3.25)$ \\
\hline \multirow{2}{*}{ Bank diversification } & $12.1432^{* * *}$ & $13.0527^{* * *}$ & $-0.1603^{* * *}$ & $-0.1592^{* * *}$ \\
\hline & $(2.80)$ & $(3.29)$ & $(-3.41)$ & $(-3.10)$ \\
\hline \multirow{2}{*}{ Bank diversification $^{2}$} & $-17.1179^{* * *}$ & $-17.3175^{* * *}$ & $0.2114^{* * *}$ & $0.2197^{* * *}$ \\
\hline & $(-3.13)$ & $(-3.86)$ & $(3.07)$ & $(3.55)$ \\
\hline \multicolumn{5}{|c|}{ Dynamic Marginal Effects } \\
\hline Lerner index critical value & 0.35 & & 0.44 & \\
\hline \multirow{2}{*}{ Lerner index long-run effect } & $4.9902^{* * *}$ & & $-1.4067^{* * *}$ & \\
\hline & $(3.57)$ & & $(-4.16)$ & \\
\hline $\begin{array}{l}\text { Five largest banks' assets } \\
\text { critical value }\end{array}$ & & $82.22 \%$ & & $85.29 \%$ \\
\hline \multirow{2}{*}{$\begin{array}{l}\text { Five largest banks' assets long- } \\
\text { run effect }\end{array}$} & & $18.0009^{* * *}$ & & $-0.3061^{* * *}$ \\
\hline & & (3.15) & & $(-2.79)$ \\
\hline $\begin{array}{l}\text { Bank diversification critical } \\
\text { value }\end{array}$ & $35.47 \%$ & $37.66 \%$ & $37.91 \%$ & $36.23 \%$ \\
\hline \multirow{2}{*}{$\begin{array}{l}\text { Bank diversification long-run } \\
\text { effect }\end{array}$} & $22.0065^{* * *}$ & $23.7451^{* * *}$ & $-0.3937^{* * *}$ & $-0.4007^{* * *}$ \\
\hline & $(4.24)$ & $(3.91)$ & $(-3.87)$ & $(-4.06)$ \\
\hline \multicolumn{5}{|c|}{ Industry-Level Control Variables } \\
\hline \multirow{2}{*}{ Bank capital } & $28.0462^{* * *}$ & $29.9941^{* * *}$ & -0.0913 & -0.0874 \\
\hline & $(5.10)$ & $(5.37)$ & $(-1.46)$ & $(-1.38)$ \\
\hline \multirow{2}{*}{ Bank liquidity } & $2.4712^{* *}$ & $3.0926^{* * *}$ & $-0.0288^{* * *}$ & $-0.0296^{* * *}$ \\
\hline & $(2.46)$ & (3.19) & $(-2.69)$ & $(-3.13)$ \\
\hline \multirow{2}{*}{ Bank performance } & $97.1732^{* * *}$ & $99.0246^{* * *}$ & $-0.5936^{* * *}$ & $-0.5218^{* * *}$ \\
\hline & $(7.48)$ & $(9.15)$ & $(-4.77)$ & $(-4.06)$ \\
\hline \multirow{2}{*}{ Bank development } & $2.3528^{* * *}$ & $2.1263^{* *}$ & $-0.0275^{* *}$ & $-0.0238^{* *}$ \\
\hline & $(2.61)$ & $(2.14)$ & $(-2.46)$ & $(-2.11)$ \\
\hline \multirow{2}{*}{ Operating efficiency } & $2.1149^{*}$ & 0.5639 & 0.0092 & 0.0085 \\
\hline & $(1.78)$ & $(0.93)$ & $(0.88)$ & $(0.51)$ \\
\hline \multicolumn{5}{|c|}{ Macroeconomic-Level Control Variables } \\
\hline \multirow{2}{*}{ Economic growth } & $2.4741^{* * *}$ & $3.0927^{* * *}$ & $-0.1319^{* * *}$ & $-0.1536^{* * *}$ \\
\hline & $(2.69)$ & $(3.28)$ & $(-4.37)$ & $(-4.93)$ \\
\hline \multirow{2}{*}{ Inflation } & $-3.1524^{* *}$ & $-3.2719^{* *}$ & $0.0394^{* * *}$ & $0.0441^{* * *}$ \\
\hline & $(-2.06)$ & $(-2.31)$ & $(3.62)$ & $(2.66)$ \\
\hline
\end{tabular}


Jorge Andrés Muñoz-Mendoza • Sandra María Sepúlveda-Yelpo • Carmen Lissette Veloso-Ramos • Carlos Leandro Delgado-Fuentealba

\begin{tabular}{|l|c|c|c|c|}
\hline \multirow{2}{*}{ Variables } & \multicolumn{4}{|c|}{ Dependent variable is financial stability } \\
\cline { 2 - 5 } & \multicolumn{2}{|c|}{ Bank Z-Score } & \multicolumn{2}{c|}{ Bank Risk } \\
\hline \multirow{2}{*}{ Institutional development } & $0.0163^{* * *}$ & $0.0179^{* * *}$ & $-0.0281^{* *}$ & $-0.0307^{* * *}$ \\
\hline \multirow{2}{*}{ Crisis } & $(3.00)$ & $(2.84)$ & $(-2.51)$ & $(-2.94)$ \\
\hline First order autocorrelation test & -0.0159 & -0.0926 & $0.0168^{* * *}$ & $0.0109^{* *}$ \\
\hline Second order autocorrelation & $(-0.45)$ & $(-0.61)$ & $(3.05)$ & $(2.44)$ \\
\hline test & $-3.73^{* * *}$ & $-3.03^{* * *}$ & $-2.88^{* * *}$ & $-2.92^{* * *}$ \\
\hline Sargan test & -0.97 & -1.02 & -0.86 & -0.93 \\
\hline $\begin{array}{l}\text { Unit root test for dependent } \\
\text { variable }\end{array}$ & 39.02 & 38.73 & 43.17 & 46.48 \\
\hline VIF test & $-25.48^{* * *}$ & $-25.48^{* * *}$ & $-21.99 * * *$ & $-21.99^{* * *}$ \\
\hline
\end{tabular}

Notes: All GMM estimations include dummy variables to control for year, income level, and zone effects. Unit root corresponds to the test proposed by Im et al. (2003). Dynamics marginal effects were calculated after the GMM estimator through bootstrapping. Z-statistics in bracket. Superscripts $* * *, * *, *$ indicate statistical significance at 1,5 , and 10 percent, respectively.

Source: Authors elaboration.

\section{CONCLUSIONS}

Financial stability in the banking system has been and will be a relevant issue for the macroeconomic and financial functioning of a country. Due to its systemic relevance, several researches have empirically analyzed their determinants in order to establish patterns that facilitate the design of national financial policies. The banking industry worldwide has experienced significant changes. Undoubtedly, the globalization of international markets, higher foreign investment, and lower financial barriers have had an impact on banking markets. During the last twenty years, the banking market has become more concentrated in few institutions and diversified its financial services portfolio.

These changes in the structure and nature of banking services have had an impact on financial stability. Even though there is no consensus in the literature, diverse researches have shown that market concentration and income diversification promote financial stability. However, other studies have generated a debate about these relationships by providing contrary evidence. This debate has been made even more relevant because structural differences between countries, in terms of market concentration and income diversification, could have different effects on banking stability and therefore different ways for the design and implementation of the financial policy. 
Our investigation deepens our understanding of this matter, analyzing the effects of market concentration and income diversification on financial stability. The empirical contributions and implications of our research are summarized in two points. First, our results show that a more concentrated market structure increases financial stability of banking sector. However, the relationship between financial stability and market concentration is nonlinear. The nonlinearity shape suggests that in case of high market concentration levels, financial stability is reduced. These results are robust in terms of the market concentration measures used in this research. These findings have important implications for banks and regulators. For banks, our results provide evidence that shows that market concentration has limited benefits on banking stability and high concentration could generate adverse selection problems on the credit quality of costumer portfolio. Even setting higher interest rates associated with higher market concentration would have limited benefits for banks. For policymakers-for example, for the design of the regulatory framework of the Basel Committee on Banking Supervision-, our results provide quantifiable parameters for financial policy design aimed at limiting banking concentration and decreasing its negative consequences on industry stability.

Second, income diversification also strengthens financial stability. This result supports that the financial stability of banking industry is nourished by the economies of scope developed by these institutions and by multi-product industry qualities. However, we also observe that its effects on financial stability are nonlinear, ratifying that economies of scope and economies of scale generate a trade-off on stability. The nonlinearity shape shows that for high income diversification levels, economies of scope generate an adverse selection problem on financial products portfolio. This problem reduces stability and increases risk for banks. Our results establish relevant implications for banks in different countries and for policymakers that regulate the banking industry, since they allow them to establish policy parameters over nontraditional activities and evaluate their benefits and risks on banking stability. Even our results suggest that banks should reduce their diversification degree according to economic cycle to mitigate bank risk in economic activity contraction periods.

From these results, future lines of research can be established. The stability of banking, and the effects of market concentration and income diversification on it, could be conditioned by institutional development in different countries. This edge would open new approaches for the design of financial policy aimed at banking stabilization, where the institutional environment is another channel that determines long-term banking stability. 
Jorge Andrés Muñoz-Mendoza • Sandra María Sepúlveda-Yelpo • Carmen Lissette Veloso-Ramos •

Carlos Leandro Delgado-Fuentealba

\section{REFERENCES}

1. Agoraki, M., Delis, M., \& Pasiouras, F. (2011). Regulations, competition and bank risk-taking in transition countries. Journal of Financial Stability, 7(1), 38-48. https:// doi.org/10.1016/j.jfs.2009.08.002.

2. Allen, F., \& Gale, D. (2000). Comparing financial systems. MIT Press, Cambridge, Massachussetts.

3. Amidu, M., \& Wolfe, S. (2013). Does bank competition and diversification lead to greater stability? Evidence from emerging markets. Review of Development Finance, 3(3), 152-166. https://doi.org/10.1016/j.rdf.2013.08.002.

4. Arellano, M., \& Bover, O. (1995). Another look at the instrumental variable estimation of error-components models. Journal of Econometrics, 68(1), 29-51. https://doi. org/10.1016/0304-4076(94)01642-D.

5. Athanasoglou, P., Brissimis, S., \& Delis, M. (2008). Bank-specific, industry specific and macroeconomic determinants of bank profitability. Journal of International Financial Markets, Institutions and Money, 18(2), 121-136. https://doi.org/10.1016/j. intfin.2006.07.001.

6. Batten, J., \& Vo, X. (2016). Bank risk shifting and diversification in an emerging market. Risk Management, 18(4), 217-235. https://doi.org/10.1057/s41283-016-0008-2.

7. Beck, T., Demirgüç-Kunt, A., \& Levine, R. (2006). Bank concentration, competition, and crises: First results. Journal of Banking and Finance, 30(5), 1581-1603. https://doi. org/10.1016/j.jbankfin.2005.05.010.

8. Beck, T., Dermigüç-Kunt, A., \& Levine, R. (2007). Bank Concentration and Fragility: Impact and Mechanics. National Bureau of Economic Research, Volume Title: The Risks of Financial Institutions. Chicago: Chicago University Press.

9. Beck, T., De Jonghe, O., \& Schepens, G. (2013). Bank competition and stability: Cross-country heterogeneity. Journal of Financial Intermediation, 22 (2), 218-244. https:// doi.org/10.1016/j.jfi.2012.07.001.

10. Berger, A., Hasan, I., Korhonen, I., \& Zhou, M. (2010a). Does diversification increase or decrease bank risk and performance? Evidence on diversification and the risk-return tradeoff in banking (June 21, 2010). BOFIT Discussion Paper No. 9/2010. http:// dx.doi.org/10.2139/ssrn.1651131.

11. Berger, A., Hasan, I., \& Zhou, M. (2010b). The effects of focus versus diversification on bank performance: Evidence from Chinese banks. Journal of Banking and Finance, 34(7), 1417-1435. https://doi.org/10.1016/j.jbankfin.2010.01.010.

12. Berger, A., Klapper, L., \& Turk-Ariss, R. (2009). Bank competition and financial stability. Journal of Financial Services Research, 35 (2), 99-118. https://doi.org/10.1007/ s10693-008-0050-7.

13. Besanko, D., \& Thakor, A. (1993). Relationship banking, deposit insurance and bank portfolio. In: Mayer, C., \& Vives, X. (Eds.), Capital Markets and Financial Intermediation. Cambridge University Press, Cambridge, UK, 292-318. 
14. Boyd, J., \& De Nicolo, G. (2005). The theory of bank risk taking and competition revisited. The Journal of Finance, 60(3), 1329-1343.

15. Boyd, J., De Nicolo, G., \& Jalal, A. (2006). Bank risk taking and competition revisited: new theory and evidence. IMF Working Paper 06/297.

16. Boyd, J., \& Graham, S. (1988). The profitability and risk effects of allowing bank holding companies to merge with other financial firms: A simulation study. Federal Reserve Bank of Minneapolis Quarterly Review, 12(2), 476-514.

17. Boyd, J., Graham, S., \& Hewitt, R. (1993). Bank holding company mergers with nonbank financial firms: Effects on the risk of failure. Journal of Banking and Finance, 17(1), 43-63. https://doi.org/10.1016/0378-4266(93)90079-S.

18. Carletti, E., \& Vives, X. (2009). Regulation and competition policy in the banking sector. In: Vives, X. (ED.) Competition Policy in the EU: Fifty Years on from the Treaty of Rome. New York: Oxford University Press. https://doi.org/10.1093/ acprof:oso/9780199566358.003.0010.

19. Chan, Y-S., Greenbaum, S., \& Thakor A. (1986). Information reusability, competition and bank asset quality. Journal of Banking and Finance, 10(2), 243-253. https://doi. org/10.1016/0378-4266(86)90008-7.

20. Chen, S. \& Liao, C. (2011). Are foreign banks more profitable than domestic banks? Home- and host-country effects of banking market structure, governance, and supervision. Journal of Banking and Finance, 35(4), 819-839. https://doi.org/10.1016/j. jbankfin.2010.11.006.

21. Chiorazzo, V., Milani, C., \& Salvini, F. (2008). Income diversification and bank performance: Evidence from Italian banks. Journal of Financial Services Research, 33(3), 181-203. https://doi.org/10.1007/s10693-008-0029-4.

22. Demirgüç-Kunt, A., \& Huizinga, H. (2000). Financial structure and bank profitability. Policy Research Working Paper Series No. 2430. Washington, DC: The World Bank.

23. Demirgüç-Kunt, A., \& Huizinga, H. (2010). Bank activity and funding strategies: The impact on risk and return. Journal of Financial Economics, 98(3), 626-650. https://doi. org/10.1016/j.jfineco.2010.06.004.

24. Demirgüç-Kunt, A., Laeven, L., \& Levine, R. (2004). Regulations, market structure, institutions, and the cost of financial intermediation. Journal of Money, Credit, and Banking, 36(3), 593-622. https://www.jstor.org/stable/3838956.

25. DeYoung, R., \& Roland, K. (2001). A risk-return framework for multiple-product industries. In Emmanuel Acar (Ed.), Added Value in Financial Institutions: Risk or Return? London: Financial Times/Prentice Hall, 193-198.

26. Fernández, A., González, F., \& Suárez, N. (2010). How institutions and regulation shape the influence of bank concentration on economic growth: International evidence. International Review of Law and Economics, 30(1), 28-36. https://doi.org/10.1016/j. irle.2009.09.001.

27. Freixas, X., \& Rochet, J. (2008). Microeconomics of banking. Second Edition, MIT Press. 
Jorge Andrés Muñoz-Mendoza • Sandra María Sepúlveda-Yelpo • Carmen Lissette Veloso-Ramos • Carlos Leandro Delgado-Fuentealba

28. Gelos, G. (2009). Banking spreads in Latin America. Economic Inquiry, 47 (4), 796-814. https://doi.org/10.1111/j.1465-7295.2008.00144.x.

29. Goddard, J., McKillop, D., \& Wilson, J. (2008). The diversification and financial performance of US credit unions. Journal of Banking and Finance, 32 (9), 1836-1849. https://doi.org/10.1016/j.jbankfin.2007.12.015.

30. Goddard, J., Molyneux, P., \& Wilson, J. (2004). The profitability of European banks: A cross-sectional and dynamic panel analysis. The Manchester School, 72 (3), 363-381. https://doi.org/10.1111/j.1467-9957.2004.00397.x.

31. Gregoire, J., \& Mendoza, M. (1990). Estructura del mercado financiero. Estudios de Economía, 17(1), 57-70.

32. Hauswald, R., \& Marquez, R. (2006). Competition and strategic information acquisition in credit markets. The Review of Financial Studies, 19(3), 967-1000. https://doi. org/10.1093/rfs/hhj021.

33. Hellmann, T., Murdock, K., \& Stiglitz, J. (2000). Liberalization, moral hazard in banking, and prudential regulation: Are capital requirements enough? The American Economic Review, 90(1), 147-165. https://www.jstor.org/stable/117285.

34. Im, K., Pesaran, M., \& Shin, Y. (2003). Testing for unit roots in heterogeneous panels. Journal of Econometrics, 115(1), 53-74. https://doi.org/10.1016/S0304-4076(03)00092-7

35. Jara, M., Arias, J., \& Rodriguez, A. (2014). Determinants of bank performance: Evidence for Latin America. Academia Revista Latinoamericana de Administración, 27(2), 164-182. https://doi.org/10.1108/ARLA-04-2013-0030.

36. Jeon, J., \& Kyu, K. (2013). Bank competition and financial stability: A comparison of commercial banks and mutual savings banks in Korea. Pacific-Basin Finance Journal, 25, 253-272. https://doi.org/10.1016/j.pacfin.2013.10.003.

37. Jiménez, G., López, J., \& Saurina, J. (2013). How does competition impact bank risk-taking? Journal of Financial Stability, 9(2), 185-195. https://doi.org/10.1016/j. jfs.2013.02.004.

38. Judson, R., \& Owen, A. (1999). Estimating dynamic panel data models: A guide for macroeconomists. Economics Letter, 65 (1), 9-15. https://doi.org/10.1016/ S0165-1765(99)00130-5.

39. Keeley, M. (1990). Deposit insurance, risk, and market power in banking. The American Economic Review, 80(5), 1183-1200. https://www.jstor.org/stable/2006769.

40. King, R., \& Levine, R. (1993). Finance and growth: Schumpeter might be right. The Quarterly Journal of Economics, 108(3), 717-737. https://doi.org/10.2307/2118406.

41. Klein, M. (1971). A theory of the banking firm. Journal of Money, Credit and Banking, 3(2), 205-218. https://www.jstor.org/stable/1991279.

42. Köhler, M. (2015). Which banks are more risky? The impact of business models on bank stability. Journal of Financial Stability, 16, 195-212. https://doi.org/10.1016/j. jfs.2014.02.005. 
43. Laeven, L., \& Levine, R. (2009). Bank governance, regulation and risk taking. Journal of Financial Economics, 93(2), 259-275. https://doi.org/10.1016/j.jfineco.2008.09.003.

44. Landi A., \& Venturelli V. (2001). The diversification strategy of European banks: Determinants and effects on efficiency and profitability. EFMA 2001 Lugano Meetings. http://dx.doi.org/10.2139/ssrn.269841.

45. Lee, C., Hsieh, M., \& Yang, S. (2014). The relationship between revenue diversification and bank performance: Do financial structures and financial reforms matter? Japan and the World Economy, 29, 18-35. https://doi.org/10.1016/j.japwor.2013.11.002.

46. Liu, H., Molyneux, P., \& Nguyen, L. (2012). Competition and risk in South East Asian commercial banking. Applied Economics, 44(28), 3627-3644. https://doi.org/10.1080/ 00036846.2011 .579066$.

47. Martinez-Peria, M., \& Mody, A. (2004). How foreign participation and market concentration impact bank spreads: Evidence from Latin America. Journal of Money, Credit and Banking, 36(3), 511-537. https://www.jstor.org/stable/3838950.

48. Marquez, R. (2002). Competition, adverse selection, and information dispersion in the banking industry. The Review of Financial Studies, 15(3), 901-926. https://doi. org/10.1093/rfs/15.3.901.

49. Martinez-Miera, D., \& Repullo, R. (2010). Does competition reduce the risk of bank failure? The Review of Financial Studies, 23(10), 3638-3664. https://doi.org/10.1093/ rfs/hhq057.

50. Matutes, C., \& Vives, X. (2000). Imperfect competition, risk taking and regulation in banking. European Economic Review, 44(1), 1-34. https://doi.org/10.1016/ S0014-2921(98)00057-9.

51. Maudos, J., \& Solís, L. (2009). The determinants of net interest income in the Mexican banking system: An integrated model. Journal of Banking and Finance, 33(10), 1920-1931. https://doi.org/10.1016/j.jbankfin.2009.04.012.

52. Mercieca, S., Schaeck, K., \& Wolfe, S. (2007). Small European banks: Benefits from diversification? Journal of Banking and Finance, 31(7), 1975-1998. https://oi. org/10.1016/j.jbankfin.2007.01.004.

53. Mirzaei, A., Liu, G., \& Moore, T. (2011). Does market structure matter on banks' profitability and stability? Emerging versus advanced economies. Economics and Finance Working Paper Series, Department of Economics and Finance, Working Paper No. 11-12. London: Brunel University of London.

54. Molyneux, P., \& Thornton, J. (1992). Determinants of European bank profitability: A note. Journal of Banking and Finance, 16(6), 1173-1178. https://doi. org/10.1016/0378-4266(92)90065-8.

55. Monti, M. (1972). Deposit, credit, and interest rate determination under alternative bank objectives. In Szego, G. P. \& Shell, K. (Eds.), Mathematical methods in investment and finance. Amsterdam: North-Holland.

56. Petersen, M., \& Rajan, R. (1995). The effect of credit market competition on lending relationships. The Quarterly Journal of Economics, 110(2), 407-443. https://doi. org/10.2307/2118445. 
Jorge Andrés Muñoz-Mendoza • Sandra María Sepúlveda-Yelpo • Carmen Lissette Veloso-Ramos • Carlos Leandro Delgado-Fuentealba

57. Rose, P. (1989). Diversification of the banking firm. The Financial Review, 24(2), $251-280$

58. Schaeck, K., Cihak, M., \& Wolfe, S. (2009). Are competitive banking systems more stable? Journal of Money, Credit and Banking, 41(4), 711-734. https://doi. org/10.1111/j.1538-4616.2009.00228.x.

59. Shim, J. (2013). Bank capital buffer and portfolio risk: The influence of business cycle and revenue diversification. Journal of Banking and Finance, 37(3), 761-772. https:// doi.org/10.1016/j.jbankfin.2012.10.002.

60. Smith, B. (1984). Private information, deposit interest rates and the stability of the banking system. Journal of Monetary Economics, 14(3), 293-317. https://doi. org/10.1016/0304-3932(84)90045-X.

61. Soedarmono, W., Machrouh, F., \& Tarazi, A. (2013). Bank competition, crisis and risk taking: Evidence from emerging markets in Asia. Journal of International Financial Markets, Institutions and Money, 23, 196-221. https://doi.org/10.1016/j.intfin.2012.09.009.

62. Stiglitz, J., \& Weiss, A. (1981). Credit rationing in markets with imperfect information. The American Economic Review, 71(3), 393-410. http://www.jstor.org/ stable/1802787.

63. Stiroh, K. (2004a). Do community banks benefit from diversification? Journal of Financial Service Research, 25(2-3), 135-160. https://doi. org/10.1023/B:FINA.0000020657.59334.76.

64. Stiroh, K. (2004b). Diversification in banking: Is noninterest income the answer? Journal of Money, Credit and Banking, 36(5), 853-882. https://doi.org/10.1353/ mcb.2004.0076.

65. Stiroh, K. (2006). New evidence on the determinants of bank risk. Journal of Financial Services Research, 30(3), 237-263. https://doi.org/10.1007/s10693-006-0418-5.

66. Stiroh, K., \& Rumble, A. (2006). The dark side of diversification: The case of US financial holding companies. Journal of Banking and Finance, 30(8), 2131-2161. https:// doi.org/10.1016/j.jbankfin.2005.04.030.

67. Tabak, B., Fazio, D., \& Cajueiro, D. (2012). The relationship between banking market competition and risk-taking: Do size and capitalization matter? Journal of Banking and Finance, 36(12), 3366-3381. https://doi.org/10.1016/j.jbankfin.2012.07.022.

68. Templeton, W., \& Severiens, J. (1992). The effects of non-bank diversification on bank holding company risk. Quarterly Journal of Business and Economics, 31 (4), 3-17. http://www.jstor.org/stable/40473066.

69. Tsai, Y., Lin, C., \& Chen, H. (2015). Optimal diversification, bank value maximization and default probability. Applied Economics, 47(24), 2488-2499. https://doi.org/10.108 0/00036846.2015.1008766.

70. Turk-Ariss, R. (2010). On the implications of market power in banking: Evidence from developing countries. Journal of Banking and Finance, 34(4), 765-775. https:// doi.org/10.1016/j.jbankfin.2009.09.004. 
71. Uhde, A., \& Heimeshoff, U. (2009). Consolidation in banking and financial stability in Europe: Empirical evidence. Journal of Banking and Finance, 33(7), 1299-1311. https://doi.org/10.1016/j.jbankfin.2009.01.006.

72. Vives, X. (2016). Competition and stability in banking: The role of regulation and competition policy. Princeton: Princeton University Press, 2016. http://www.jstor.org/stable/j. ctt1q1xs80.

73. Williamson, S.D. (1986). Costly monitoring, loan contracts and equilibrium credit rationing. The Quarterly Journal of Economics, 102(1), 135-146. https://www.jstor.org/ stable/1884684.

74. Yahya, A., Akhtar, A., \& Tabash, M. (2017). The impact of political instability, macroeconomic and bank-specific factors on the profitability of Islamic banks: An empirical evidence. Investment Management and Financial Innovations, 14(4), 30-39. https://oi. org/10.21511/imfi.14(4).2017.04. 